\title{
Analisis Tarif Pengelolaan Sampah berdasarkan Ability To Pay danWillingness To Pay di Kecamatan Cimahi Tengah
}

\section{ZAMADI LA ROSYI DA HASBULLAH ${ }^{1}$, KANCITRA PHARMAWATI ${ }^{1}$, YULI ANTI PRATAMA ${ }^{1}$}

1. Jurusan Teknik Lingkungan, Institut Teknologi Nasional (Itenas), Bandung Email:zrosyidahasbullah@gmail.com

\begin{abstract}
ABSTRAK
Kecamatan Cimahi Tengah merupakan pusat Kota Cimahi yang terdapat aktivitas didalamnya seperti pemukiman, perkantoran, pusat perbelanjaan, pusat pendidikan militer yang menghasilkan sampah dalam kegiatan sehari-hari. Timbulan sampah domestik di Kecamatan Cimahi Tengah sebesar 53,36 ton/hari. Biaya pembuangan sampah ke Tempat Pemrosesan Akhir (TPA) Sarimukti mengalami kenaikan dari Rp. 29.000 menjadi Rp. 50.000 per ton sampah, tahun 2016 target retribusi masyarakat sebesar 8\%, namun target retribusi hanya mencapai 5,8\%, sehingga beban yang ditanggung pemerintah meningkat. Studi ini bertujuan untuk mengetahui Ability To Pay (ATP) dan Willingness To Pay (WTP) masyarakat di Kecamatan Cimahi Tengah berdasarkan kelas daya listrik, kelas II rumah dengan daya listrik 500 watt sampai dengan 1300 watt dan kelas III rumah dengan daya listrik 250 watt sampai dengan 500 wattterhadap pengelolaan sampah. Metode yang digunakan adalah survei, wawancara, kuesioner, ATP, WTP menggunakan Contingent Valuation Method (CVM). Nilai ATP yang diperoleh pada kelas II dan kelas III adalah Rp. 12.701 dan Rp. 6.829, serta nilai WTP Rp. 7.492 dan Rp. 3.439.
\end{abstract}

Kata kunci: pengelolaan sampah, ATP, WTP, CVM

\begin{abstract}
Cimahi Tengah sub-district is the center of Cimahi City which has activities inside such as residential, office, health center, military education center which produce garbage in daily activities. Domestic waste generation in Kecamatan Cimahi Tengah is 53.36 ton / day. The cost of garbage disposal to Sarimukti Final Processing Place (TPA) increased from Rp. 29,000 to Rp. 50,000 per ton of garbage, by 2016 the target of community retribution is $8 \%$, but the retribution target is only $5.8 \%$, so the government will increase. This study is to determine the ability to pay (ATP) and the willingness to pay (WTP) of the community in the District of Central Cimahi based on electric power class, class II house with 500 watts of power up to 1300 watts and class III houses with 250 watts of power up to 500 watts on waste management. The method used is survey, interview, questionnaire, ATP, WTP using Contingency Assessment Method (CVM). ATP value obtained in class II and class III is Rp. 12,701 and Rp. 6,829, and WTP value Rp. 7,492 and Rp. 3.439.
\end{abstract}

Keywords: waste management, ATP, WTP, CVM 


\section{PENDAHULUAN}

Timbulan sampah terbesar di Kota Cimahi berasal dari sumber pemukiman, dimana Kecamatan Cimahi Tengah memiliki timbulan sampah 53,36 ton/hari (Dinas Lingkungan Hidup Kota Cimahi, 2016).Kecamatan Cimahi Tengah merupakan pusat Kota Cimahi yang memiliki luas 10,11 km² dengan jumlah penduduk 169.677 jiwa dan tingkat kepadatan penduduk terbesar yaitu 16.778 jiwa $/ \mathrm{km}^{2}$ (Badan Pusat Statistik, 2016).

Berdasarkan Peraturan Daerah Kota Cimahi Nomor 2 Tahun 2012 tentang Retribusi Jasa Umum menjelaskan bahwa tarif pengelolaan sampah dibagi menjadi tiga kelas yaitu kelas I untuk rumah dengan daya listrik lebih besar dari 1300 watt sebesar Rp. 8.000, kelas II untuk rumah dengan daya listrik 500 watt sampai dengan 1300 watt sebesar Rp. 6.500 dan kelas III untuk rumah dengan daya listrik 250 watt sampai dengan 500 watt sebesar Rp. 5.000, dimana tarif tersebut merupakan pelayanan untuk pengumpulan, pengangkutan dan pemrosesan. Saat ini biaya pembuangan sampah Kota Cimahi ke Tempat Pemrosesan Akhir (TPA) Sarimukti mengalami kenaikan yang semula Rp. 29.000 menjadi Rp. 50.000 per ton sampah (Dinas Lingkungan Hidup Kota Cimahi, 2016), dengan adanya kenaikan ini tentunya akan mempengaruhi biaya yang dikeluarkan pemerintah dan mempengaruhi retribusi masyarakat. Pada tahun 2016 subsidi dari pemerintah sebesar 92\% dan target retribusi masyarakat sebesar $8 \%$, namun target retribusi hanya mencapai 5,8\% dari target yang telah ditetapkan, sehingga beban yang ditanggung pemerintah meningkat (Dinas Lingkungan Hidup Kota Cimahi, 2016).

Aspek pembiayaan merupakan aspek yang sangat penting dalam pengelolaan sampah. Aspek pembiayaan dapat dikatakan sebagai ujung tombak dalam pengelolaan sampah karena akan mempengaruhi aspek yang lainnya terutama dalam aspek teknis operasional seperti dalam penyediaan sarana dan prasarana pengelolaan sampah. Pada umumnya pembiayaan pengelolaan sampah berasal dari subsidi pemerintah dan retribusi yang dibebankan kepada masyarakat dan (Indramawan, 2014).

Hal ini dapat mempengaruhi peningkatan jumlah pemasukan pendapatan dalam pengelolaan sampah yang nantinya digunakan untuk menutupi pengeluaran dan peningkatan pelayanan pengelolaan sampah (Indramawan, 2014). Penyesuaian tarif jasa pelayanan pengelolaan sampah ini sangat penting, dimana masyarakat pengguna jasa pelayanan pengelolaan sampah harus sesuai dan tidak merasa keberatan dengan tarif yang ditetapkan. Pada tahun 2018 Pemerintah Kota Cimahi akan melakukan kajian penetapan tarif jasa pelayanan pengelolaan sampah, dimana tarif tersebut akan digunakan untuk tarif jasa pelayanan pengelolaan sampah tahun 2019, oleh karena itu diperlukan kajian kemampuan dan kemauan masyarakat untuk membayar jasa pelayanan pengelolaan sampah.

Tujuan yang ingin dicapai dalam penelitian yaitu, mengetahui nilai kemampuan membayar dan kemauan membayar terhadap jasa pelayanan pengelolaan sampah.

\subsection{Studi Literatur}

\section{METODOLOGI}

Studi literatur dilakukan untuk mempelajari teori-teori yang berhubungan dengan penelitian, sumber literatur diperoleh dari berbagai buku, jurnal serta informasi lain.

\subsection{Survei}


Survei dilakukan untuk mengetahui daerah terlayani dengan menanyakan kepada Ketua Rukun Warga (RW) mengenai adanya kegiatan pengumpulan sampah dan tarif pengumpulan sampah.

\subsection{Persiapan Penelitian}

Persiapan penelitian pada penelitian ini antara lain:

a. Penentuan lokasi penelitian

Lokasi penelitian, yaitu Kecamatan Cimahi Tengah yang terdiri dari enam kelurahan sebanyak 110 rukun warga (RW) dan mendapatkan jasa pelayanan pengelolaan sampah.

b. Desain kuesioner

Kuesioner yang diberikan ke responden diharapkan dapat menggambarkan ATP dan WTP, kuesioner terbagi menjadi: (1) Identifikasi karakteristik responden meliputi umur, jenis kelamin, pendidikan terakhir dan pekerjaan; (2) Komponen ATP meliputi pendapatan; (3) Komponen WTP, yaitu besaran rupiah yang dikeluarkan responden yang digunakan untuk menghitung rata-rata WTP.

\subsection{Teknik Sampling}

Penelitian ini menggunakan teknik stratified rancom sampling,yaitu teknik pengambilan sampel dari suatu populasi secara stratifikasi. Penentuan jumlah sampel menggunakan Rumus Slovin (Sugiyono, 2010).

$$
n=\frac{N}{1+N e^{2}}
$$

dimana

$\mathrm{n} \quad=$ jumlah sampel

$\mathrm{N} \quad=$ jumlah populasi

e $\quad=$ tingkat error $(10 \%)$

Penentuan jumlah sampel dilihat dari proporsi kelas II dibandingkan kelas III, sedangkan jumlah sampel disetiap kelurahan dilihat dari jumlah kartu keluarga, semakin banyak jumlah kartu keluarga, semakin banyak jumlah sampel di kelurahan tersebut.

\subsection{J enis Data}

Data yang digunakan dalam penelitian ini adalah: (1) Data primer yang digunakan adalah pendapatan dan besar kemauan membayar jasa pelayanan pengelolaansampah; (2) Data sekunder yang digunakan adalah data kependudukan dan kondisi sosial ekonomi dan sistem pengelolaan sampah eksisting.

\subsection{Analisis Pengolahan Data}

\subsubsection{Perhitungan Ability To Pay (ATP)}

Ability to pay (ATP)adalah kemampuan seseorang untuk membayar jasa pelayanan yang telah diterimanya berdasarkan penghasilan yang dianggap ideal. Besarnya ATP adalah rasio alokasi anggaran untuk membayar tarif terhadap total pendapatan. ATP dihitung dengan pendekatan pendapatan dikali persen retribusi pengelolaan sampah, persentase nilai ATP untuk retribusi sampah tingkat kota sebesar 0,7\% (Susanto, 2016)dapat dilihat pada rumus berikut.

$$
\mathrm{ATP}=\text { Pendapatan } \times 0,7 \%
$$




\subsubsection{Perhitungan Willigness To Pay (WTP) Menggunakan Contingent Valuation \\ Method}

Untuk mendapatkan nilai WTP menggunakan CVM terdapat beberapa tahap yaitu (Indramawan, 2014) :

a. Membangun pasar hipotesis

Pasar hipotesis dibuat untuk menduga faktor-faktor yang mempengaruhi kemauan membayar jasa pelayanan pengelolaan sampah di Kecamatan Cimahi Tengah.

b. Mendapatkan nilai WTP

Nilai WTP diperoleh secara langsung dimana responden menuliskan sendiri besar biaya yang bersedia dikeluarkan untuk membayar jasa pelayanan pengelolaan sampah.

c. Menghitung dugaan rata-rata WTP

Nilai dugaan rata-rata WTP, yaitu jumlah keseluruhan nilai WTP dibagi jumlah responden, dapat dilihat pada rumus berikut:

dimana

$$
E W T P=\frac{\sum_{i}^{n} W_{i}}{n}
$$

EWTP = estimasi rata-rata WTP

$\mathrm{Wi} \quad=$ nilai WTP ke-i

$\mathrm{n} \quad=$ jumlah sampel

d. Kurva WTP

Kurva WTP menggambarkan hubungan nilai WTP dengan jumlah responden yang bersedia mengeluarkan biaya untuk jasa pelayanan pengelolaan sampah.

e. Menjumlahkan data (Total WTP)

Proses dimana rata-rata penawaran dikalikan total populasi.

$$
T W T P=\sum_{t=0}^{n} W T P i \times n_{i}
$$

dimana

TWTP = estimasi rata-rata WTP

WTPi = nilai WTP ke-i

$\mathrm{n}_{\mathrm{i}} \quad=$ jumlah sampel ke-i yang bersedia membayar sebesar WTP

$\mathrm{i} \quad=$ responden ke-i yang bersedia membayar $(\mathrm{i}=1,2,3 \ldots \mathrm{n})$

f. Mengevaluasi penggunaan CVM

Penelitian menggunakan CVM untuk penilaian barang lingkungan dilihat dari nilai $\mathrm{R}^{2}$ adjusted minimal diperoleh 0,15 atau $15 \%$ adalah penelitian yang baik (Garrot dan Willis dalam Gusti Elfa, 2009). $R^{2}$ adjusted ini dijadikan sebagai pengukuran seberapa baik regresi mendekati nilai data asli yang dibuat model, untuk mengetahui nilai $\mathrm{R}^{2}$ adjusted dilakukan regresi linier berganda dengan memberi skor pada setiap jawaban responden dan di input ke SPSS 16.

\section{HASI L DAN PEMBAHASAN}

\subsection{Pelaksanaan Survei}

\subsubsection{Daerah Telayani}


Hasil survei ke 110 RW di Kecamatan Cimahi Tengah menunjukkan bahwa tidak semua RW terlayani oleh petugas pengumpul sampah yang bekerjasama dengan ketua RW, Gambar 1 persentase daerah terlayani di Kecamatan Cimahi Tengah.

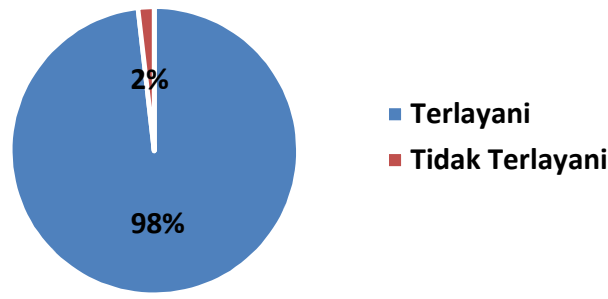

\section{Gambar 1 Persentase Daerah Terlayani di Kecamatan Cimahi Tengah (Sumber: Hasil Survei, 2017)}

Berdasarkan Gambar 1, terdapat 98\% dari jumlah RW di Kecamatan Cimahi Tengah terlayani oleh jasa pelayanan pengelolaan sampah dan $2 \%$ dari jumlah di Kecamatan Cimahi Tengah tidak terlayani oleh jasa pelayanan pengelolaan sampah karena membuang sampah ke sungai dan membakar sampah.

\subsubsection{Tarif Pengelolaan Sampah}

Berdasarkan Peraturan Daerah Kota Cimahi Nomor 2 Tahun 2012 tentang Retribusi Jasa Umum, terbagi menjadi tiga kelas, yaituKelas I untuk rumah dengan daya listrik lebih besar dari 1.300 watt sebesar Rp. 8.000, kelas II untuk rumah dengan daya listrik 500 watt sampai 1.300 watt sebesar Rp. 6.500 dan kelas III untuk rumah dengan daya listrik 250 watt sampai 500 watt sebesar Rp. 5.000.Berikut Gambar 2jumlah rumah terlayani di Kecamatan Cimahi Tengah.

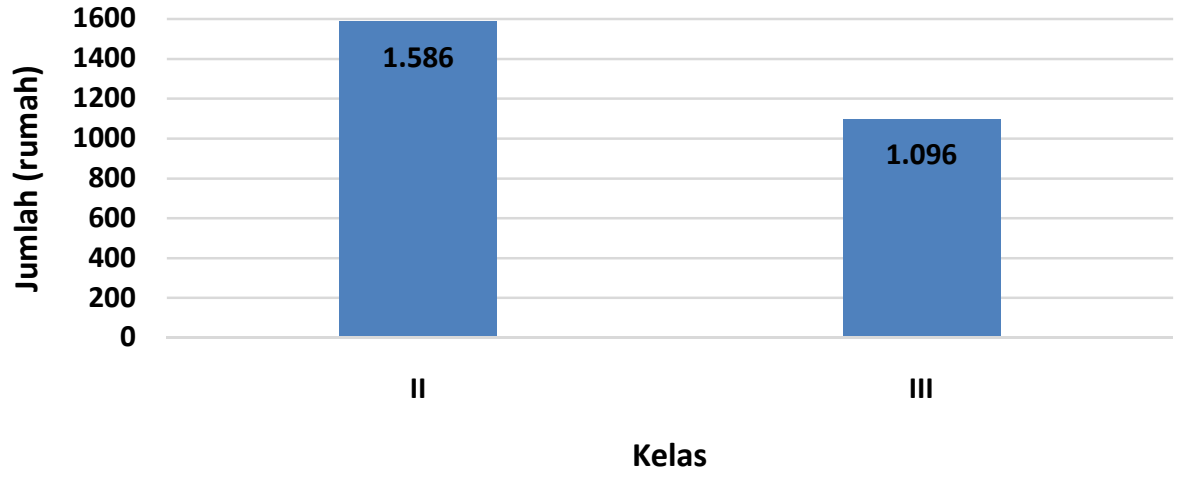

Gambar 2 J umlah Rumah Terlayani (Sumber: DLH, 2016)

Berdasarkan Gambar 2 menunjukkan tidak terdapat jumlah rumah kelas I, karena retribusi yang masuk hanya kelas II dan kelas III, jumlah rumah yang termasuk kelas II sebesar 1.586 rumah dan kelas III sebesar 1.096 rumah di Kecamatan Cimahi Tengah yang membayar tarif jasa pelayanan pengelolaan sampah.

\subsection{Penentuan Responden}

Jumlah penduduk di Kecamatan Cimahi Tengah sebesar 2.682 rumah terlayani jasa pelayanan pengelolaan sampah, digunakan rumus slovin untuk menentukan jumlah sampel dengan tingkat error $10 \%$.Penentuan jumlah sampel dilihat dari proporsi kelas II dibandingkan kelas III, yaitu 59\%: 41\%. Tabel 1 adalah jumlah sampel di setiap kelurahan. 


$$
n=\frac{2.682 \text { rumah terlayani }}{1+2.682 \text { rumah terlayani } 0,1^{2}}=99,96 \approx 100 \text { sampel }
$$

Tabel 1 J umlah Sampel di Setiap Keluarahan

\begin{tabular}{|c|c|c|c|}
\hline \multirow{2}{*}{ No } & \multirow{2}{*}{ Kelurahan } & \multicolumn{2}{|c|}{ J umlah Sampel } \\
\hline & & Kelas II & Kelas I I I \\
\hline 1 & Kelurahan Baros & 9 & 6 \\
\hline 2 & Kelurahan Cigugur & 11 & 8 \\
\hline 3 & Kelurahan Karangmekar & 9 & 6 \\
\hline 4 & Kelurahan Setiamanah & 10 & 7 \\
\hline 5 & Kelurahan Padasuka & 11 & 8 \\
\hline 6 & Kelurahan Cimahi & 9 & 6 \\
\hline & J umlah & 59 & 41 \\
\hline
\end{tabular}

Sumber: Hasil Perhitungan, 2017.

\subsection{Karakteristik Responden}

\subsubsection{Karakteristik Umum}

Karakteristik umum pada penelitian ini yaitu:

a. Umur

Umur berpengaruh terhadap pola pikir, semakin tinggi umur diharapkan semakin dewasa dan bijaksana, dimana dapat mempengaruhi kemampuan dan kemauan seseorang untuk membayar jasa pengelolaan sampah (Indramawan, 2014). Gambar 3a adalah persentase umur responden yang diteliti. Sebesar 52\% responden berumur lebih besar dari 40 tahun, sebesar 36\% responden berumur 30 tahun sampai 40 tahun dan $12 \%$ responden berumur 20 tahun hingga 30 tahun.

b. Jenis kelamin

Perempuan dianggap lebih besar kemampuan dan kemauan untuk membayar jasa pelayanan pengelolaan sampah karena secara lahiriah perempuan membersihkan rumah dan membuang sampah, sehingga memiliki kesadaran dan tanggungjawab lebih terhadap kebersihan (Indramawan, 2014).Gambar 3b adalah persentase jenis kelamin responden yang diteliti, sebesar $53 \%$ responden perempuan dan $47 \%$ responden laki-laki.

c. Pendidikan

Tingkat pendidikan mempengaruhi pemahaman dan penilaian akan pentingnya lingkungan, semakin tinggi pendidikan seseorang, semakin memahami pentingnya pengelolaan sampah termasuk kemampuan dan kemauan untuk membayar jasa pelayanan pengelolaan sampah. Gambar $\mathbf{4 a}$ adalah persentase tingkat pendidikan responden, sebesar 33\% responden dengan tingkat pendidikan SMA, sebesar 31\% responden dengan tingkat pendidikan SMP, sebesar $27 \%$ responden dengan tingkat pendidikan SD dan sebesar $9 \%$ responden dengan tingkat pendidikan sarjana.

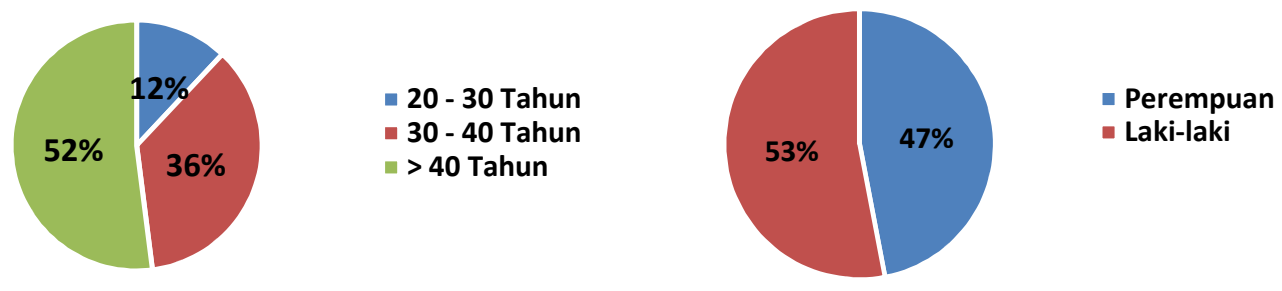

a 
d. Pekerjaan

Pekerjaan berpengaruh dalam menentukan kemampuan dan kemauan masyarakat untuk membayar jasa pelayanan pengelolaan sampah, jika seseorang memiliki pekerjaan maka akan menentukan pendapatan yang memutuskan orang tersebut memiliki kemampuan dan kemauan untuk membayar jasa pelayanan pengelolaan sampah (Indramawan, 2014). Gambar 4b adalah persentase pekerjaan responden, sebesar $59 \%$ responden bekerja di sektor swasta, sebesar 39\% responden adalah ibu rumah tangga dan sebesar $19 \%$ responden sebagai pegawai negeri sipil.

e. Pendapatan

Pendapatan menentukan seseorang memiliki kemampuan dan kemauan untuk membayar jasa pelayanan pengelolaan sampah, semakin tinggi pendapatan maka permintaan untuk peningkatan kualitas lingkugan akan semakin tinggi (Indramawan, 2014). Gambar 4c adalah persentase pendapatan responden, sebesar $30 \%$ responden memiliki pendapatan $\mathrm{Rp}$. 2.645.000, sebesar $28 \%$ responden memiliki pendapatan Rp. 500.000 sampai Rp. 1.000 .000 , sebesar $26 \%$ responden memiliki pendapatan Rp. 1.000 .000 sampai Rp. 1.500.000, dan $16 \%$ responden memiliki pendapatan Rp. 0 sampai Rp. 500.000 .

f. Jumlah anggota keluarga

Semakin banyak jumlah anggota keluarga maka akan mempengaruhi besarnya pengeluaran rumah tangga termasuk kemampuan dan kemauan membayar jasa pelayanan pengelolaan sampah (Indramawan, 2014). Gambar 4d adalah persentase jumlah anggota keluarga, sebesar $60 \%$ responden memiliki jumlah anggota keluarga lebih dari 4 orang dan $40 \%$ responden memiliki jumlah anggota keluarga kurang dari 4 orang.
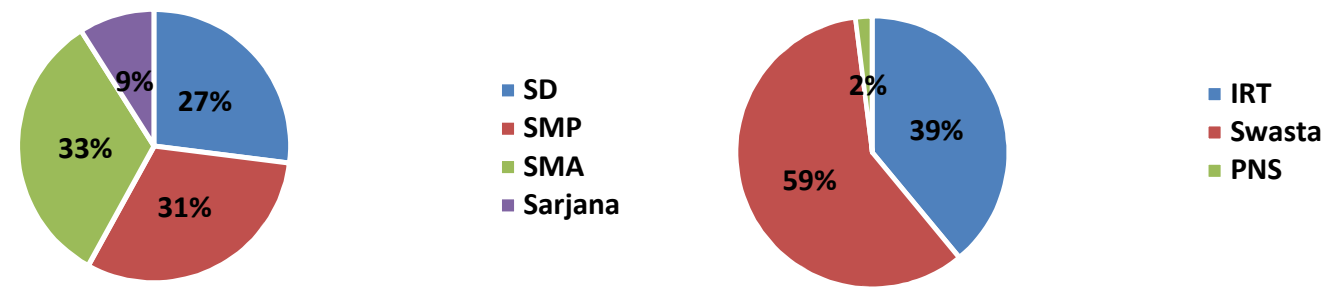

a
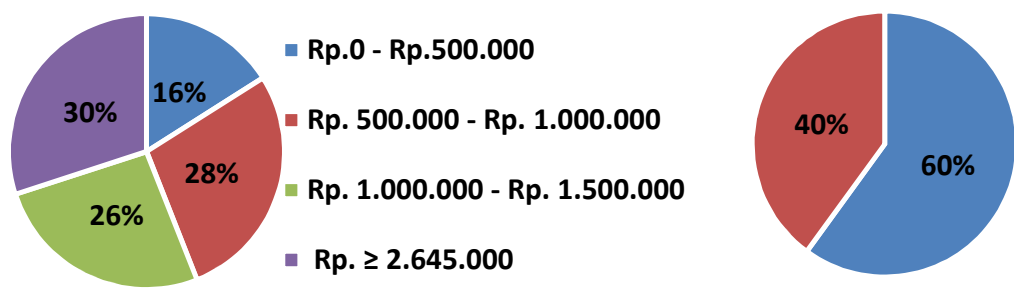

b

C

\section{d}

- $>4$ orang

$-<4$ orang

Gambar 4Grafik Responden (a) Pendidikan Terakhir; (b) Pekerjaan; (c) Pendapatan ; (d) J umlah Anggota Keluarga(Sumber : Hasil Pengolahan Data, 2017)

\subsubsection{Pendapat dan Pengetahuan Responden Mengenai Pengelolaan Sampah}

Berikut adalah hasil kuesioner yang disebarkan:

a. Ketepatan waktu petugas pengumpul sampah

Semakin tepat waktu petugas mengumpulkan sampah, semakin besar kemauan masyarakat untuk membayar jasa pelayanan pengelolaan sampah. Gambar 5aadalah persentase ketepatan waktu petugas mengumpulkan sampah, sebesar $72 \%$ responden merasa petugas sudah tepat waktu dan $28 \%$ responden merasa belum tepat waktu. 
b. Kepuasan terhadap jasa pelayanan pengelolaan sampah

Semakin puas responden terhadap jasa pelayanan pengelolaan sampah, semakin besar kemauan responden untuk membayar jasa pelayanan pengelolaan sampah.Gambar $\mathbf{5 b}$ adalah persentase kepuasan responden terhadap jasa pelayanan pengelolaan sampah, sebesar $62 \%$ responden sudah merasa puas terhadap jasa pelayanan pengelolaan sampah dan 38\% responden tidak merasa puas.

c. Manfaat yang dirasakan

Semakin besar manfaat yang dirasakan terhadap pengelolaan sampah, semakin besar kemauan seseorang untuk membayar jasa pelayanan pengelolaan sampah.Gambar $\mathbf{5 c a d a l a h ~ p e r s e n t a s e ~ m a n f a a t ~ y a n g ~ d i r a s a k a n ~ r e s p o n d e n , ~ s e b e s a r ~}$ $58 \%$ responden sudah merasakan manfaat pengelolaan sampah dan $42 \%$ responden belum merasakan manfaat pengelolaan sampah.

d. Pengetahuan mengenai Peraturan Daerah Kota Cimahi Nomor 2 Tahun 2012

Semakin besar pengetahuan responden terhadap peraturan dapat meningkatkan kesadaran dan kewajiban untuk membayar jasa pelayanan pengelolaan sampah. Gambar 5d adalah persentase pengetahuan responden terhadap peraturan, sebesar $88 \%$ responden tidak mengetahui peraturan dan $12 \%$ responden mengetahui peraturan tersebut.

e. Kesediaan membayar jasa pelayanan pengelolaan sampah

Semakin besar kesediaan untuk membayar jasa pelayanan pengelolaan sampah, semakin besar pemerintah untuk meningkatkan tarif jasa pelayanan pengelolaan sampah.Gambar 5eadalah persentase kesediaan responden membayar jasa pelayanan pengelolaan sampah, sebesar 93\% bersedia untuk membayar jasa pelayanan pengelolaan sampah dan $7 \%$ responden tidak bersedia.

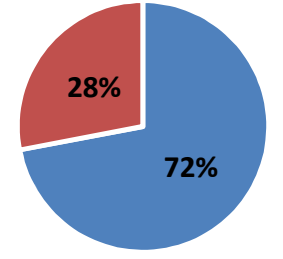

- Sudah Tepat Waktu

- Belum Tepat Waktu

a

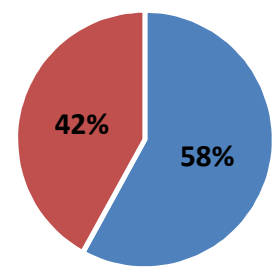

- Sudah Merasakan Manfaat

- Belum Merasakan Manfaat

c

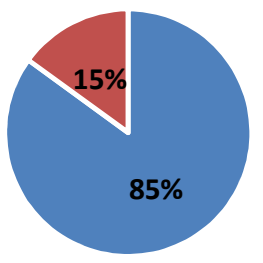

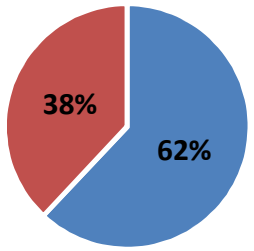

- Puas

- Tidak Puas

b

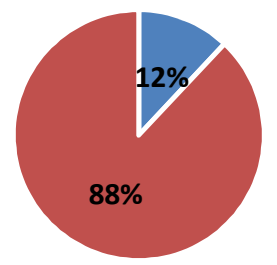

- Ya Mengetahui

- Tidak Mengetahui

d

- Ya Bersedia

- Tidak Bersedia

Gambar 5 Grafik Reseponden. (a) Ketepatan Waktu Pengumpulan; (b) Kepuasan Responden Terhadap J asa Pelayanan Pengelolaan Sampah; (c) Manfaat Pengelolaan Sampah; (d) Pengetahuan Peraturan Daerah Kota Cimahi Nomor 2 Tahun 2012; (e) Kesediaan Membayar Jasa Pelayanan Pengelolaan Sampah (Sumber : Hasil Pengolahan Data, 2017) 


\subsection{Perhitungan Ability To Pay (ATP)}

Penelitian ini mengelompokan besaran ATP berdasarkan kelas daya listrik, Gambar 6adalah rata-rata ATP di Kecamatan Cimahi Tengah.

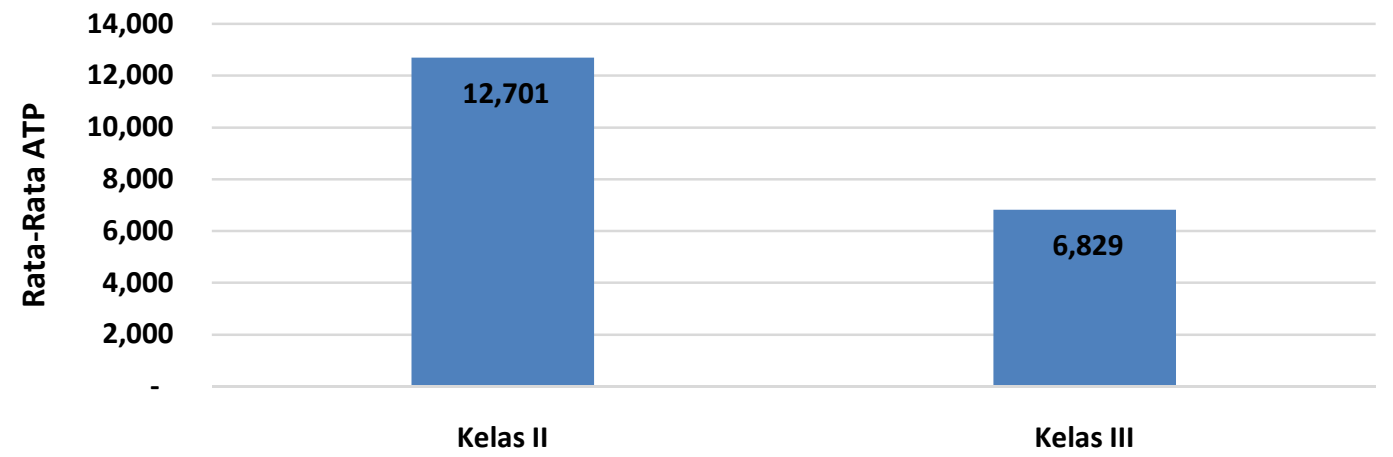

\section{Gambar 6. Rata-Rata ATP (Sumber : Hasil Perhitungan,2017)}

Berdasarkan Gambar 6nilai rata-rata ATP terbesar terdapat pada responden kelas II yaitu rumah dengan daya listrik 500 watt sampai dengan 1300 watt sebesar Rp. 12.701, sedangkan nilai rata-rata ATP terkecil terdapat pada responden kelas III yaitu rumah dengan daya listrik 250 watt sampai dengan 500 watt sebesar Rp. 6.829. Jika dibandingkan dengan Peraturan Daerah Kota Cimahi Nomor 2 tentang Retribusi Jasa Umum untuk kelas II Rp.6.500 dan kelas III Rp.5.000, maka masyarakat memiliki kemampuan yang besar untuk membayar jasa pelayanan pengelolaan sampah.

\subsection{Perhitungan Willingness To Pay (WTP) Menggunakan Contingent Valuation Method(CVM)}

Terdapat enam tahapan untuk menghitung WTP yaitu:

a. Membangun pasar hipotesis

"Kemauan responden untuk membayar jasa pelayanan pengelolaan sampah diduga akan dipengaruhi secara signifikan oleh umur responden, jenis kelamin responden, tingkat pendidikan responden, pekerjaan, pendapatan responden, jumlah anggota keluarga dan ketepatan waktu petugas pengumpul sampah.

b. Mendapatkan nilai WTP

Dilakukan dengan caraopen ended questiondimana responden menuliskan sendiri besaran rupiah yang dikeluarkan.

c. Menghitung dugaan rata-rata nilai WTP

Penelitian ini mengelompokkan nilai dugaan rata-rata WTP berdasarkan kelas daya listrik, Gambar 7adalah nilai dugaan rata-rata WTP.

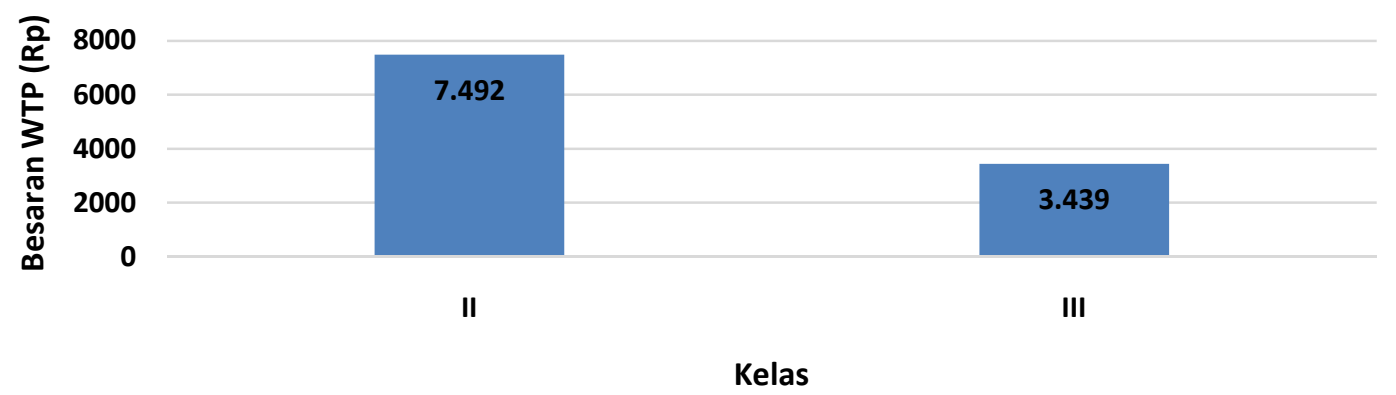

Gambar 7. Rata-Rata WTP (Sumber : Hasil Perhitungan,2017) 
Berdasarkan Gambar 7nilai rata-rata WTP terbesar terdapat pada responden kelas II yaitu rumah dengan daya listrik 500 watt sampai dengan 1300 watt sebesar Rp. 7.492, sedangkan nilai rata-rata WTP terkecil terdapat pada responden kelas III yaitu rumah dengan daya listrik 250 watt sampai dengan 500 watt sebesar Rp. 3.349. Jika dibandingkan dengan Peraturan Daerah Kota Cimahi Nomor 2 tentang Retribusi Jasa Umum, maka masyarakat memiliki kemauan untuk membayar jasa pelayanan pengelolaan sampah sebesar Rp. 3.349 sampaiRp. 7.492.

d. Kurva WTP

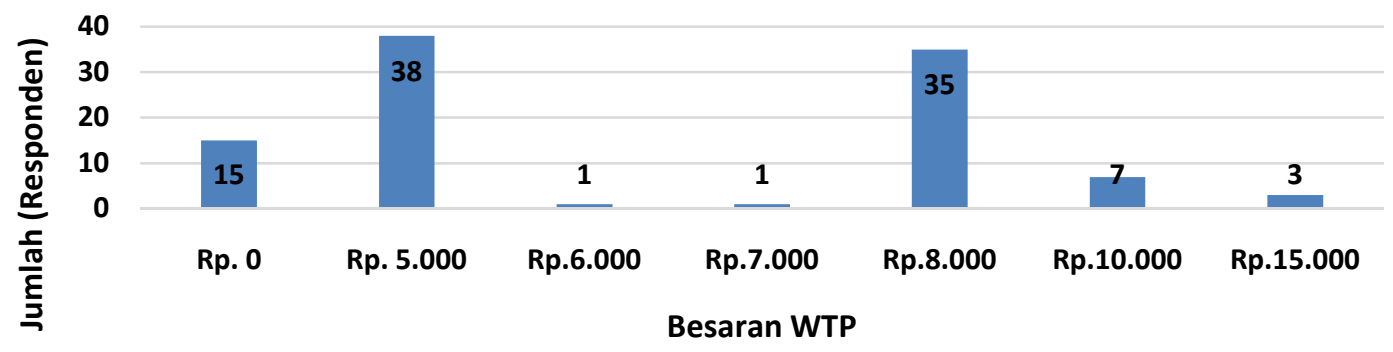

Gambar 8. Kurva WTP (Sumber : Hasil Perhitungan, 2017)

Berdasarkan Gambar 8 menunjukan bahwa WTP yang dikeluarkan oleh responden untuk membayar jasa pelayanan pengelolaan sampah sebesar Rp. 5.000 pada 38 responden dan Rp. 8.000 pada 35 responden.

e. Menjumlahkan data (Total WTP)

Proses dimana rata-rata WTP dikalikan terhadap total populasi, Tabel 4adalah total WTP di Kecamatan Cimahi Tengah.

\begin{tabular}{c|cccc} 
Kelas & Rata-Rata WTP & $\begin{array}{c}\text { Tabel 4 Total WTP } \\
\text { Populasi } \\
\text { (Rumah) }\end{array}$ & $\begin{array}{c}\text { Waktu } \\
\text { (Bulan) }\end{array}$ & Total WTP \\
\hline II & Rp. 7.492 & 1.586 & 12 & Rp. 142.587.456 \\
\hline III & Rp. 3.439 & 1.096 & 12 & Rp. 45.229.728 \\
\hline \multicolumn{5}{r}{ Jumlah } \\
\hline
\end{tabular}

Sumber : Hasil Perhitungan, 2017

Berdasarkan Tabel 4 menunjukkan bahwa total WTP merupakan potensi retribusi jasa pelayanan pengelolaan sampah di Kecamatan Cimahi Tengah sebesar Rp. Rp. 188.087.184 per tahun.

f. Mengevaluasi Penggunaan CVM

Untuk mendapatkan nilai $R^{2}$ adjusteddengan cara regresi linier berganda dimana setiap jawaban akan diberikan skor, dapat dilihat Tabel $\mathbf{5}$ panduan skoring kuesioner dan Tabel 6adalah nilai hasil uji regresi linier berganda.

Tabel 5 Panduan Skor Kuesioner

\begin{tabular}{|c|c|c|c|}
\hline No & Variabel & Kategori & Skor \\
\hline 1 & Umur & $\begin{array}{l}\text { 20-30 Tahun } \\
\text { 30-40 Tahun } \\
>40 \text { Tahun }\end{array}$ & $\begin{array}{l}1 \\
2 \\
3\end{array}$ \\
\hline 2 & Jenis kelamin & $\begin{array}{l}\text { Laki-laki } \\
\text { Perempuan }\end{array}$ & $\begin{array}{l}1 \\
2\end{array}$ \\
\hline 3 & Tingkat pendidikan & $\begin{array}{l}\text { SD } \\
\text { SMP }\end{array}$ & $\begin{array}{l}1 \\
2\end{array}$ \\
\hline
\end{tabular}




\begin{tabular}{|c|c|c|c|}
\hline No & Variabel & Kategori & Skor \\
\hline & & SMA & 3 \\
\hline & & Sarjana & 4 \\
\hline \multirow{4}{*}{4} & \multirow{4}{*}{ Pekerjaan } & IRT & 1 \\
\hline & & Swasta & 2 \\
\hline & & PNS & 3 \\
\hline & & Pengusaha & 4 \\
\hline \multirow{4}{*}{5} & \multirow{4}{*}{ Pendapatan } & Rp. 0 - Rp. 500.000 & 1 \\
\hline & & Rp. $500.000-$ Rp. 1.000 .000 & 2 \\
\hline & & Rp. $1.000 .000-$ Rp. 1.500 .000 & 3 \\
\hline & & Rp. $\geq 2.645 .000$ & 4 \\
\hline \multirow{2}{*}{6} & \multirow{2}{*}{ Jumlah anggota keluarga } & $>4$ orang & 1 \\
\hline & & $<4$ orang & 2 \\
\hline \multirow{2}{*}{7} & Ketepatan waktu petugas & Belum tepat waktu & 1 \\
\hline & penqumpul sampah & Sudah tepat waktu & 2 \\
\hline
\end{tabular}

Tabel 6 Hasil Uji Regresi Linier Berganda

\begin{tabular}{lccl}
\hline \multicolumn{1}{c}{ Variabel } & Koefisien & Sig. & \multicolumn{1}{c}{ Keterangan } \\
\hline Umur (X1) & $-239,142$ & 0,576 & Pengaruh Tidak Signifikan \\
\hline Jenis kelamin (X2) & $-550,102$ & 0,466 & Pengaruh Tidak Signifikan \\
\hline Pendidikan (X3) & 376,065 & 0,377 & Pengaruh Tidak Signifikan \\
\hline Pekerjaan (X4) & $-158,275$ & 0,823 & Pengaruh Tidak Signifikan \\
\hline Pendapatan (X5) & 1327,060 & 0,001 & Pengaruh Signifikan \\
\hline Jumlah anggota keluarga (X6) & $-706,655$ & 0,249 & Pengaruh Tidak Signifikan \\
\hline $\begin{array}{l}\text { Ketepatan waktu petugas } \\
\text { pengumpul sampah (X7) }\end{array}$ & $1.580,676$ & 0,023 & Pengaruh Signifikan \\
\hline Sumber: Hasi Pengolahan Data 2017 & & &
\end{tabular}

Sumber : Hasil Pengolahan Data, 2017.

BerdasarkanTabel 6 menunjukkan bahwa variabel tingkat pendapatan responden dan ketepatan waktu petugas pengumpul sampah adalah faktor yang secara signifikan mempengaruhi WTP, karena memiliki nilai signifikansi $<0,1$. Berikut adalah persamaan regresi linier berganda :

\section{$Y=1.339,010-239,142 X_{1}-550,102 X_{2}+376,065 X_{3}-158,275 X_{4}+$ $1.327,060 X_{5^{-}} 706,655 X_{6}+1.580,676 X_{7}$

Untuk mengetahui nilai koefisien korelasi dari variabel yang terdapat dalam model regresi linier berganda, dapat diketahui dari nilai $\mathrm{R}$ Square (Koefisien Korelasi) pada Tabel 7.

Tabel 7Model Summary

\begin{tabular}{lllccc}
\hline \multicolumn{1}{c}{ Model } & $\mathbf{R}$ & $\mathbf{R}^{\mathbf{2}}$ & $\mathbf{R}^{\mathbf{2}}$ Adjusted & Std. Error of the Estimate \\
\hline 1 & 0,585 & 0,342 & 0,292 & $2.715,961$ \\
\hline Sumber : Pengolat
\end{tabular}

Sumber : Pengolahan Data, 2017. 
Berdasarkan Tabel 7menunjukkan bahwa nilai koefisien korelasi (R) antara umur, jenis kelamin, tingkat pendidikan, pendapatan, pekerjaan,jumlah anggota keluargadan ketepatan waktu petugas pengumpul sampah dengan WTP adalah 0,585, faktor tersebut memiliki hubungan dengan WTP dalam tingkat yang sedang (Sugiyono, 2010). Nilai koefisien korelasi tersebut dikuadratkan $\left(R^{2}\right)$ nilai 0,342 atau $34,2 \%$. Hasil tersebut menunjukan bahwa faktor-faktor tersebut mempengaruhi WTP sebesar $34,2 \%$, sedangkan sebesar $65,8 \%$ sisanya adalah pengaruh faktor lain yang tidak diteliti dalam penelitian ini. Untuk mengetahui kualitas model regresi dilihat dari nilai $R^{2}$ adjusted, penelitian ini dinilai baik karena nilai $R^{2}$ adjusted yang diperoleh lebih besar dari 15 persen, nilai $R^{2}$ adjusted yang diperoleh sebesar 0,292 atau 29,2\% (Garrot dan Willis dalam Gusti Elfa, 2009)

\subsection{Kaitan ATP dan WTP}

Hasil perhitungan ATP dan WTP akan dikaitkan dan dibandingkan terhadap Peraturan Daerah Kota Cimahi Nomor 2 Tahun 2012 tentang Retribusi Jasa Umum, Gambar 9adalah perbandingan rata-rata ATP dan WTP.

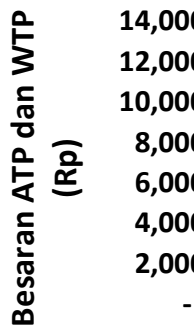

-

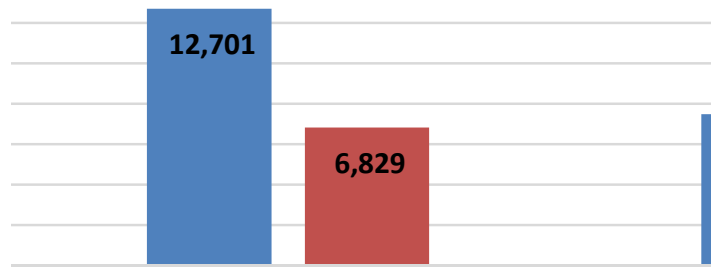

Rata-Rata ATP

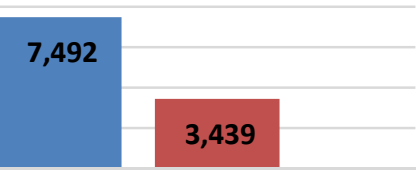

Rata-Rata WTP

- Kelas II $\quad$ Kelas III

\section{Gambar 9. Perbandingan Rata-rata ATP dan WTP (Sumber : Hasil Perhitungan,2017)}

Berdasarkan Gambar 9menunjukkan bahwa nilai rata-rata ATP lebih besar dari nilai ratarata WTP, artinya responden memiliki kemampuan membayar jasa pelayanan pengelolaan sampah yang besar daripada kemauan membayar jasa pelayananpengelolaan sampah, hal ini terjadi pada masyarakat yang memiliki pendapatan relatif tinggi, tetapi belum merasakan utilitas dari jasa pelayanan pengelolaan sampah.Berdasarkan hasil wawancara dengan responden, responden yang tidak puas dengan jasa pelayanan pengelolaan sampah karena pengumpulan sampah tidak tepat waktu sehingga terdapat sampah yang menumpuk dan tidak terangkut dirumah, oleh karena itu responden belum merasakan utilitas dari jasa pelayanan pengelolaan sampah.

\section{KESI MPULAN}

Berdasarkan hasil penelitian mengenai kemampuan dan kemauan membayar masyarakat terhadap jasa pelayanan pengelolaan sampah sebagai berikut, berdasarkan daya listrik adalah nilai ATP Rp. 12.701 dan Rp. 6.829, nilai WTP Rp. 7.492 dan Rp. 3.439. Nilai rata-rata ATP pada penelitian ini berada diatas nilai rata-rata WTP, artinya responden belum merasakan utilitas dari jasa pelayanan pengelolaan sampah. 


\section{DAFTAR RUJ UKAN}

Badan Pusat Statistik. (2016). Kecamatan Cimahi Tengah dalam Angka, Cimahi.

Dinas Lingkungan Hidup (DLH) Kota Cimahi, 2016.

Elfa, Gusty.(2009). Analisis Willingness To Pay Masyarakat Terhadap Peningkatan Pelayanan Sistem Penyediaan Air Bersih Dengan Wslic (Water Sanitation For Low Income Community) (Studi Kasus Desa Situdaun, Kecamatan Tenjolaya, Kabupaten Bogor), Institut Pertanian Bogor, Bogor.

Indramawan, Permana Dandy. (2014), Analisis Willingness To Pay Pengelolaan Sampah Terpadu di Kecamatan Semarang Barat, Universitas Diponegoro, Semarang.

Peraturan Daerah Kota Cimahi Nomor 2 Tahun 2012 tentang Retribusi Jasa Umum. Cimahi.

Susanto, Iwan. (2016), Analisis Penerimaan Retribusi Sampah oleh Masyarakat dalam Upaya Peningkatan Pelayanan Pengelolaan Persampahandi Kota Bandung Bagian Timur, Institut Teknologi Bandung, Bandung.

Sugiyono.(2010). Statistika Untuk Penelitian. Bandung: Alfabeta 